\section{Light at the end of the tunnel?}

SIR - Although the facts in a recent article on the situation in the former Soviet Union (Nature 354, 339; 1991) are correct, I cannot agree that Russian science is close to death. Rather, I believe that the collapse of the Communist regime and its consequences suggest that the present situation in Russian science is not just a dark tunnel. Now there is the prospect of a light at the end of the tunnel.

The huge centralized militarily orientated bureaucratic machine that has been Soviet science for the past 70 years allowed no innovation. It allowed only members of the Communist party to make a career in science and valued the labour of a scientist as only a fraction of that of a blue-collar worker. This machine insulated national from international science and separated research (institutes of the Academy of Sciences) from education (universities). It has to be destroyed.

The destruction of the machine means not the death of Russian science, but rather its recovery. I do not believe that Russian scientists who were able to contribute significantly to human knowledge even under the Communist regime will be less able to make similar contributions in a system based on internationally accepted principles.

Another part of the story concerns the personal fate of Soviet scientists. While a large number may lose their jobs and will therefore have to find other social roles, it is also true that the present situation demands a drastic reduction in the number of unproductive scientific institutes as well as of the many unproductive scientists working in them. To increase efficiency, Soviet science must dismiss literally thousands of able-bodied people who have hitherto spent years in their institutes playing chess, drinking tea, solving crossword puzzles and participating in party and trade union activities, and whose expertise (assuming they possessed any) was lost many years ago.

Much the same will happen in other fields, but nobody expects that the discharge of thousands of people from the huge and ineffective kolkhozes (collective farms) will mean the death of Russian agriculture.

It is unlikely that really competent scientists will fail to find a place in a new system. No nation sacrifices education even in the hardest of times, so that universities in the future may become institutions at which more scientists will find themselves doing both research and teaching. It must also be hoped that the best research institutes will not be closed. The development of private business should also eventually lead to the employment of a large number of researchers. And, last but not least, the new political changes allow young Russian scientists to train in leading foreign laboratories (as I am now).

The present difficult situation in Russia (including that in science) requires careful consideration as well as international goodwill. But the difficulties connected with the destruction of the old system are only one side of the coin. The other side is the hope for improvements stemming from the development of science in a free country.

\section{ANDREJ A. ROMANOVSKY* \\ Department of Physiology and \\ Biophysics,}

University of Tennessee,

Memphis, Tennessee 38163, USA

"Usual address: Institute of Physiology, Byelorussian Academy of Sciences, Minsk 220725, Byelorussian Republic

\section{Estonia's plight}

SIR - The sympathy that Nature demonstrates for ex-Soviet science deserves appreciation, but I am concerned that the ex-Soviet science that needs help always, in your pages, turns out to be Russian science. A recent letter from Moscow draws attention to the poor state of science "in our country (by which we mean the whole territory of the former Soviet Union, including the now independent republics)" (Nature 355, 384; 1992).

As an Estonian scientist I feel obliged to broaden the frame. I sincerely respect the best in Russian science, and it is a pity indeed that it is not compatible with the Russian economy. Nevertheless, for us, who have been living and working under Soviet Russian-speaking occupation, it is intolerable that our respected colleagues from Moscow still claim to speak on behalf of "the now independent republics". My home university in Tartu was founded by Swedes as the second Swedish university after Uppsala. As Universität zu Dorpat it was a wellknown European centre of science run by the Baltic Germans, and after the First World War it became the Estonian national university. The politics of the Russian/Soviet Empire ruined it four times. (To be honest, it has provided help to rebuild it too, twice.) Since 1944, there have been a greater number of prominent ethnic Estonian scientists abroad than in Estonia. Nevertheless, Estonians formed less than $1 / 250$ of the population of the Soviet Union, but $1 / 25$ of the 100 most cited Soviet scientists.

The economic chaos left by socialism is even worse for the smaller cultures, where educational traditions have been based on strong regional universities. The brain-drain is already devastating in the Baltics, because of the narrower culture gap with the West. We do not have huge well-equipped armies to feed, but we too are short of resources. But we have to hold out, since the fate of science in Estonia, Latvia and Lithuania (as elsewhere) determines, after all, the fate of these European nations.

JAANUS HARRO

Department of Medical Pharmacology, Uppsala University Biomedical Center, S-75124 Uppsala, Sweden

\section{Homage to Tswett}

SIR - M. S. Tswett is generally regarded as the sold discoverer of chromatography ${ }^{1,2}$. But analytical and preparative frontal paper chromatography was reported in 1861 and published in 1862 by Friedrich Goppelsroeder ${ }^{3}$, professor of chemistry at Basel University. Goppelsroeder thought that an observation by Schoenbein on differential migration of pure compounds on paper dipped in a solution would give rise to a useful analytical tool he later called Capillaranalyse (ref. 4),

Is frontal paper chromatography really chromatography? It accords with the definition of chromatography by Gordon et al..$^{5}$ as a "technical procedure of analysis by percolation of fluid through a body of comminuted or porous rigid material, irrespective of the nature of the physicochemical processes that may lead to the separation of substances in the apparatus". The most remarkable features of Goppelsroeder's work are repeated analysis, allowing "sharp separation of mixtures of dozens of compounds", identified by spectral data (sic); use of impregnated papers and other media; extensive use of specific reagents and fluorescence; spectral examination in situ; and analysis or organic and inorganic compounds, including proteins.

I believe that Tswett's important contribution was the development of initial narrow-zone and column chromatography, which allowed the development of modern techniques. Goppelsroeder did not merely perform some curious experiments on filter paper: he had a deep insight into the possibilities of the method he discovered.

\section{P. JÖSSANG}

Laboratoire de Chimie,

Museum National d'Histoire Naturelle, 63 Rue Buffon,

75005 Paris, France

1. Ettre, L. S. Int. Lab. 21(8), 18-24 (1991)

2. Chovin, P. in Chromatographie en Chimie Organique et Biologique (ed. Lederer, E.) 1, 1 (Masson, Paris, 1959). Goppelsroeder, F. Bull. Soc. Ind. Mulhouse 32, 116121 (1862)

4. Goppelsroeder F, Studien über die Anwendung der Capitlaranalyse (Birkhäuser, Basel, 1904).

5. Gordon, A. H. Martin, A. J. P. \& Synge, R. L. M. Biochem J. 38, 65-68 (1944) 